\title{
Influenza A, and Salmonella spp. in Backyard Poultry Eggs in Guatemala City
}

\author{
Dennis Guerra-Centeno ${ }^{1 *}$, Mercedes Díaz-Rodríguez ${ }^{1}$, Carlos Valdez-Sandoval ${ }^{1}$, Manuel Lepe-López ${ }^{1}$, Eduardo \\ Álvarez ${ }^{1}$, Christa Aguilar ${ }^{2}$, Carlos Hernández ${ }^{2}$ and Julio Borja ${ }^{2}$ \\ ${ }^{I}$ Instituto de Investigación en Ciencia Animal y Ecosalud, Facultad de Medicina Veterinaria y Zootecnia, Universidad de San Carlos de Guatemala \\ ${ }^{2}$ Escuela de Estudios de Postgrado, FMVZ, USAC, Guatemala \\ "Corresponding author's Email: msc.dennisguerra@ gmail.com; ORCID: 0000-0002-3021-4742
}

Received: 09 Apr. 2020

Accepted: 20 May. 2020

\begin{abstract}
Influenza A and salmonellosis are two of the most relevant zoonotic infectious diseases. Influenza A is one of the main threats to public health worldwide and is considered one of the causative agents of pandemics. Salmonellosis, meanwhile, has been identified by the World Health Organization as one of the four main causes of diarrheal diseases in the world. Poultry is an important source of both influenza A and Salmonella spp. but little is known about these potential threats in poultry products in Guatemala. The presence of influenza A virus antibodies and Salmonella spp. was studied in backyard poultry eggs sold in the El Guarda market in Guatemala City. 377 backyard poultry eggs were collected throughout seven months and sampled for hemagglutination inhibition test to determine the presence of antibodies to influenza virus A (H5N2 and H7N3) and cultured for Salmonella isolation. The eggs of chicken (Gallus gallus), turkey (Meleagris gallopavo), quail (Coturnix coturnix), mallard duck (Anas platyrhynchos) and muscovy duck (Cairina moschata) were sampled. Twenty-six percent of the eggs carried H5N2 antibodies, 27\% carried H7N3 antibodies and 1.3\% carried Salmonella spp. The presence of Escherichia coli inside the sampled eggs was an incidental common finding. These results suggest that backyard poultry eggs sold at markets could be a potential source of influenza A virus and Salmonella for the human population. The evidence found in the sampled eggs also shows that these potential pathogens are circulating in backyard poultry populations in Guatemala.
\end{abstract}

Key words: Food security, One Health, Public health, Zoonosis

\section{INTRODUCTION}

Influenza $\mathrm{A}$ and salmonellosis are the most relevant zoonotic infectious diseases (Russell et al., 2014; Lee et al., 2015). Influenza A is one of the main threats to public health worldwide and is considered as one of the highly contagious infectious entities that can cause pandemics at any time (WHO, 2005). Salmonellosis, meanwhile, has been considered by the WHO (2018) as one of the four leading causes of diarrheal diseases in the world. Enteric Salmonella causes 1.3 billion cases of gastroenteritis and 3 million deaths worldwide (Bhunia, 2018) and it is, without a doubt, the most widespread foodborne disease in Latin America (Gil and Samartino, 2001). These pathogens are two of the infectious and contagious entities that represent a permanent risk to public health whose study should be a permanent priority to ensure their prevention, control, and eradication.

Sick poultry and its products can be taken to the markets to sell for human consumption. For this reason, markets are considered as reservoirs of diseases such as avian influenza and salmonellosis (Wray et al., 1991; Cardona et al., 2009; Singh et al., 2010). Therefore, it is important to investigate the risk to humans posed by the commercialization of poultry and its products in urban markets where many people come together, who could not only become infected but spread infectious agents.

The eggs of various poultry species that are sold in markets, can be a source of zoonotic pathogens. Influenza A virus of subtype $\mathrm{H} 5 \mathrm{~N} 2$ has been detected in eggs during disease outbreaks (Cappucci et al., 1985). Highly pathogenic H5N1 influenza virus has been isolated in table eggs after a mutation of a vaccine virus in chickens (Kilany et al., 2010). The eggs have also been considered as the main vehicle for enteric Salmonella infection in humans (Telzak et al., 1990; Braden, 2006; Bhunia, 2018).

Published data about the detection of influenzavirus A and Salmonella spp. in backyard poultry eggs sold in Guatemalan markets are practically non-existent even 
though animal products not only represent a possible source of infection for humans, but also provide information about the circulation of pathogens in the environment. In response to this gap of knowledge, the presence of antibodies against two variants of Influenza A virus (H5N2, H7N3) and Salmonella spp was investigated in chicken, duck, turkey and quail eggs that are being sold for human consumption in the El Guarda market -which is popularly considered as the most important place for the trade of animals and their products in Guatemala City. Present findings provide useful public health information and epidemiological data about pathogen circulation in the backyard poultry population that represents almost half of the national poultry farming in Guatemala.

\section{MATERIALS AND METHODS}

\section{Study site}

El Guarda is a traditional market located in Guatemala City (N $14^{\circ} 36^{\prime} 48.77^{\prime \prime}$; W $\left.90^{\circ} 32^{\prime} 20.08^{\prime \prime}\right)$ and is the main center for the sale of domestic and wild animals and their products.

\section{Study design and sample collection}

A longitudinal study of exploratory scope was carried out for the present investigation. Seven backyard poultry eggs selling points were located in the El Guarda market and randomly sampled. Eggs were randomly collected from various poultry species from each of these selling points (Table 1). The eggs were collected every week from February to October 2019. Samples were taken from shell and yolk of all the eggs.

Table 1. Number of eggs collected and sampled from each species of backyard poultry in the El Guarda market, Guatemala

\begin{tabular}{lcc}
\hline Scientific name & Common name & N \\
\hline Gallus gallus & Chicken & 234 \\
Anas platyrhynchos & Mallard duck & 57 \\
Cairina moschata & Muscovy duck & 29 \\
Meleagris gallopavo & Turkey & 30 \\
Coturnix coturnix & Quail & 27 \\
Total & & 377 \\
\hline
\end{tabular}

$\mathrm{N}$ : Number of sampled eggs

\section{Sample transportation and laboratory procedures}

The samples were transported in padded boxes, made of expanded polystyrene, to the Regional Reference Laboratory of Animal Health (Larrsa), at the Veterinary and Animal Husbandry Faculty, University of San Carlos of Guatemala, in Guatemala City.

Influenzavirus A antibodies were investigated by hemagglutination inhibition tests performed according to standard procedures (OIE, 2018a), using Merial (Italy) H7 antigens, Larrsa (Guatemala) H5 antigens, Merk (Germany) isotonic PBS, Charles Rivers (USA) positive control, Transferpette (Germany) micropipettes, Nunc (Denmark) V-bottomed microtiter plates and a Barnsted (Germany) orbital shaker.

Salmonella spp. isolation was performed according to standard procedures (OIE, 2018b), using Puritan (USA) sterile cotton swabs, Merk (Germany) and Difco (USA) culture media, Difco (USA) peptonated water, a Thermo Scientific (USA) incubator, a Labconco (USA) laminar flow hood and Biometieux (France) API identification kits.

\section{RESULTS}

The findings of the present study indicated antibodies against influenza $A$ virus in several sampled eggs. Some eggs carried antibodies against H5N2, some against H7N3 and some against both. Chicken eggs were the most commonly positive eggs to both $\mathrm{H} 5 \mathrm{~N} 2$ and $\mathrm{H} 7 \mathrm{~N} 3$ influenza A antibody subtypes. However, the H7N3 variant was also detected in eggs from ducks (both species), turkeys and quails. Salmonella spp. was found in chicken and mallard duck eggs. Although this was not an initial objective of this study, Escherichia coli organisms were frequently isolated both from the shell and the interior of the sampled eggs. Table 2 shows the frequencies of positive reactors to influenza $\mathrm{A}$ antibodies, and the carriers of Salmonella and E. coli between poultry species and table 3 shows the distribution of positive samples in the sampled egg selling points at the El Guarda market. Figures 1 and 2 show the frequencies of H5N2 and H7N3 antibody titers in the sampled eggs (all species). 
Table 2. Frequency of positive samples to influenza A (H5N2 and H7N3) antibodies, Salmonella spp. and Escherichia coli in backyard poultry eggs in the El Guarda market, Guatemala

\begin{tabular}{|c|c|c|c|c|c|c|}
\hline \multirow[b]{2}{*}{ Scientific name } & \multirow[b]{2}{*}{$\mathbf{N}$} & \multicolumn{5}{|c|}{ H5N2 } \\
\hline & & H5N2 antibodies & H7N3 antibodies & $\begin{array}{c}+ \\
\text { H7N3 } \\
\text { antibodies }\end{array}$ & Salmonella spp. & Escherichia coli \\
\hline Gallus gallus & 234 & 99 & 85 & 69 & 3 & 168 \\
\hline Anas platyrhynchos & 57 & 0 & 1 & 0 & 2 & 48 \\
\hline Cairina moschata & 29 & 1 & 2 & 0 & 0 & 25 \\
\hline Meleagris gallopavo & 30 & 0 & 3 & 0 & 0 & 25 \\
\hline Coturnix coturnix & 27 & 0 & 10 & 0 & 0 & 21 \\
\hline Total & 377 & 100 & 101 & 69 & 5 & 287 \\
\hline
\end{tabular}

$\mathrm{N}$ : Number of sampled eggs

Table 3. Frequency of positive samples to influenza A (H5N2 and H7N3), Salmonella spp. and E. coli in backyard poultry eggs in the El Guarda market, Guatemala, according to the selling point.

\begin{tabular}{lccccc}
\hline Selling point & N & H5N2 & H7N3 & $\begin{array}{c}\text { Salmonella } \\
\text { spp. }\end{array}$ & E. coli \\
\hline A & 89 & 43 & 49 & 2 & 61 \\
B & 50 & 9 & 8 & 0 & 36 \\
C & 85 & 21 & 18 & 0 & 71 \\
D & 28 & 4 & 4 & 0 & 23 \\
E & 60 & 8 & 12 & 3 & 43 \\
F & 57 & 14 & 8 & 0 & 47 \\
G & 8 & 1 & 2 & 0 & 6 \\
\hline
\end{tabular}

$\mathrm{N}$ : Number of sampled eggs

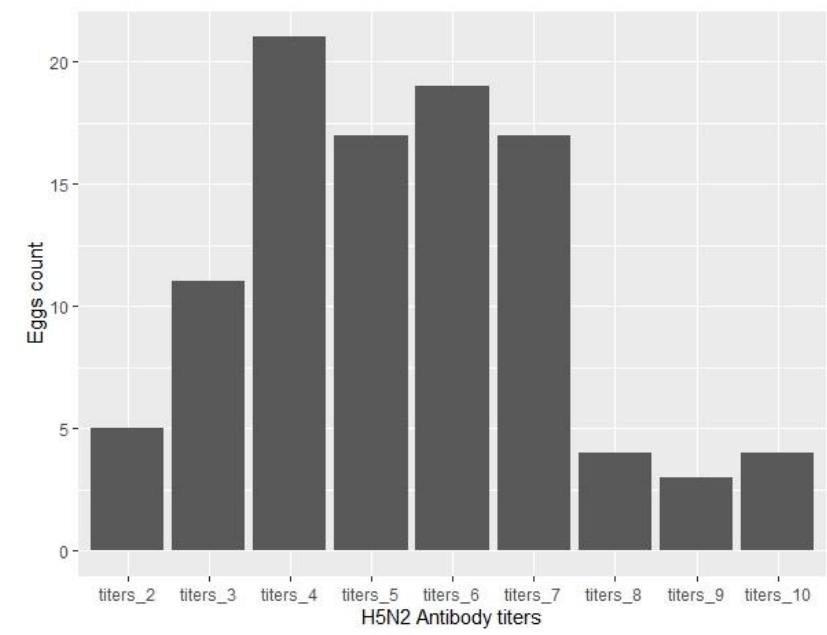

Figure 1. Frequency of logarithmic antibody titers of avian influenza A H5N2 variant in the sampled eggs.

\section{DISCUSSION}

The observed frequencies of influenza A virus subtypes $\mathrm{H} 5 \mathrm{~N} 2$ and H7N3 antibodies in the sampled chicken eggs (42.3\% and $36.3 \%$ respectively) are epidemiologically interesting especially considering that they probably come from unvaccinated backyard populations. There is some

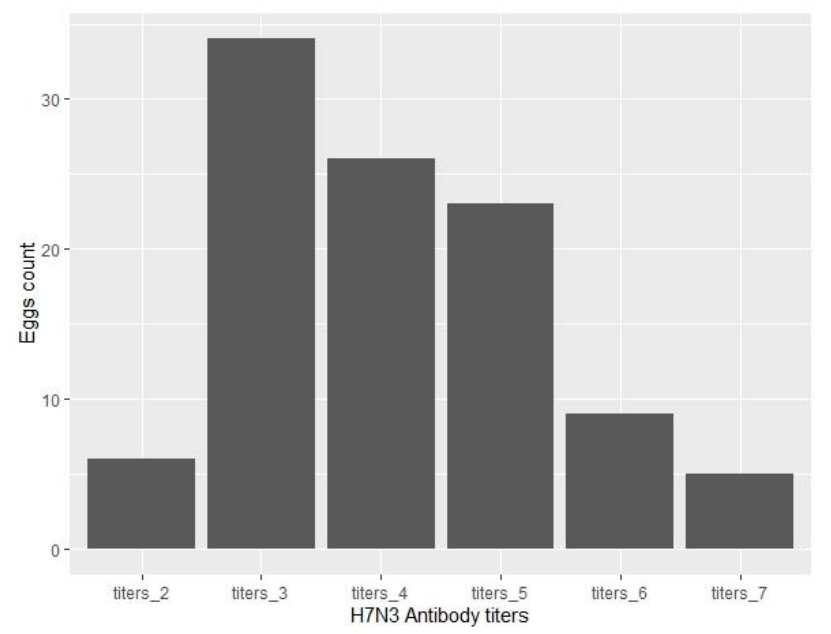

Figure 2. Frequency of logarithmic antibody titers of influenza A virus subtype H7N3 in the sampled eggs.

evidence indicating that Guatemalan peasants do not vaccinate their backyard poultry (Aguilar-Miller et al., 2016; Aquino-Sagastume et al., 2016; Mérida-Ruiz et al., 2016). In recent years the government passed a law for massive vaccination against the H7N3 type, however, this vaccination was intended to cover only those backyard poultry populations inside a $3 \mathrm{~km}$ radius around 
commercial poultry farms (Ministry of Agriculture, Livestock and Food, Guatemala, 2019). Therefore, the detected blood antibodies would indicate field exposure to influenza viruses and, by extension, the possibility of viral particles passing to the eggs from viremic chickens.

Another important issue to consider was the fact that, in backyard conditions, a hen lays around 30 eggs per year, in batches of about 10 eggs (Sonaiya et al., 1999). This means that if a market vendor wishes to maintain a constant supply of eggs throughout the year, he is forced to purchase eggs coming from several hens from several backyard flocks, from many parts of the country, suggesting that influenza $A$ virus subtypes $\mathrm{H} 5 \mathrm{~N} 2$ and H7N3 could be ubiquitous in Guatemalan rural landscapes.

On the other hand, the presence of circulating antibodies against influenza virus $\mathrm{A}$ in mallard ducks, muscovy ducks, turkeys, and quails is an uncommon finding for Guatemala and perhaps the first published report. These antibodies could be either the result of vaccination response or a challenge with field viruses. Although a H5N1 vaccine designed for chicken induced immunity in ducks and geese (Tian et al., 2005) it is unlikely that the government vaccination program has covered the entire territory of Guatemala.

The findings of the present study also support the previous observations of influenza A subtypes H5N2 and $\mathrm{H} 7 \mathrm{~N} 3$ variants in both wild and farm avian populations of Guatemala (Gonzalez-Reiche et al., 2012; GonzalezReiche and Perez, 2012; Jarquin et al., 2015; Lee et al., 2015). Although the antibodies found in the eggs may come from vaccinated individuals, there is some evidence of post-vaccination outbreaks in poultry populations (Kilany et al., 2010).

In this study, Salmonella was detected in chickens and mallard ducks, but the frequencies were rather low. Salmonella had previously been reported in chicken meat in Guatemala (Jarquín et al., 2015). Salmonellosis cases have also been reported in humans in some provinces of the country (Díaz et al., 2015).

An incidental but significant finding of the present study was the overall frequency $(76.43 \%)$ of $E$. coli isolations from the interior of the sampled eggs. Not only does this indicate a pathogen-permeable egg but also a public health concern because E. coli from domestic animal populations use to become multiresistant (Krumperman, 1983; Kojima et al., 2005; Sayah et al., 2005). It is known that antibiotic-resistant $E$. coli present in chicken meat can colonize the human bowel after consumption (Linton et al., 1977). The contamination of foods with bacteria from farm animals has been identified as a relevant problem, especially from the One Health approach (Van den Bogaard and Stobberingh, 2000).

From a public health perspective, the presence of Salmonella and E. coli and the possible presence of influenza A viruses is relevant in a country like Guatemala, where the consumption of raw eggs with orange juice and the feeding of young children with boiled under-cooked eggs is traditional.

Finally, although 18 influenza A virus subtypes have been found in migratory ducks in Guatemala (GonzalezReiche et al., 2017), the governmental surveillance system is only looking for two subtypes (H5N2 and H7N3). This situation generates a knowledge gap about the subtypes that could be circulating in poultry farm and backyard populations, as well as in poultry products for human consumption.

\section{CONCLUSION}

Antibodies against influenza A, subtypes H5N2 and H7N3 were common findings in the eggs of backyard poultry. This means that, under certain conditions, the eggs could also be a source of viral particles for consumers. Salmonella spp. was not a frequent finding in this study and Escherichia coli (both outside and inside most of the studied eggs) was an incidental finding.

\section{DECLARATIONS}

\section{Acknowledgements}

This research was co-financed by Dirección General de Investigación, University of San Carlos of Guatemala, budget line 4.8.63.7.19, year 2019 .

\section{Competing interests}

The authors have declared that no competing interest exists.

\section{Consent to publish}

The authors grant the publisher the sole and exclusive license of the full copyright in the contribution. Consequently, the publisher shall have the exclusive right throughout the world to publish and sell the contribution in all languages and all other forms of electronic publication.

\section{Author's contribution}

DG-C conception, design and drafting the manuscript, MD-R conception, design, interpretation of data and reviewing the manuscript, CV-S fund 
management, data analysis and reviewing the manuscript, ML-L data analysis and interpretation and reviewing the manuscript, EA, CA, CE and JB sampling, management of samples and reviewing the manuscript.

\section{REFERENCES}

Aguilar-Miller H, Guerra-Centeno D, Valdez-Sandoval C, Monterroso P and Anleu RG (2016). Estudio serológico de anticuerpos contra patógenos comunes, en gallinas de patio de la aldea El Caoba, Reserva de la Biosfera Maya, Guatemala. Revista Naturaleza, Sociedad y Ambiente, 3(1): 95-106. Avalaible at: http://revistacunsurori.com/index.php/revista/article/view/18/18

Aquino-Sagastume E, Guerra-Centeno DS, Valdez-Sandoval C, Villatoro F, Villatoro D and Santizo B (2016). Exploratory serosurvey for antibodies to avian pathogens in backyard chickens from a satellite community of Jalapa City, Guatemala. Ciencia, Tecnología y Salud, 3(2):

157-166. DOI: http://dx.doi.org/10.36829/63CTS.v3i2.\%25

Bhunia AK (2018). Salmonella enterica. In D. Heldman (Editor), Foodborne Microbial Pathogens. Food Science Text Series. Springer, New York, p. 271-287 (Us). DOI: https://doi.org/10.1007/978-1-4939-7349-1_15

Braden CR (2006). Salmonella enterica serotype Enteritidis and eggs: a national epidemic in the United States. Clinical Infectious Diseases, 43(4): 512-517. DOI: https://doi.org/10.1086/505973

Cappucci DT, Johnson DC, Brugh M, Smith TM, Jackson CF, Pearson JE and Senne DA (1985). Isolation of avian influenza virus (subtype H5N2) from chicken eggs during a natural outbreak. Avian Diseases, 29(4): 1195-1200. DOI: https://doi.org/10.2307/1590473

Cardona C, Yee K and Carpenter T (2009). Are live bird markets reservoirs of avian influenza?. Science Association, 88(4): 856-859. DOI: https://doi.org/10.3382/ps.2008-00338

Díaz SL, Jarquin C, Morales AJ, Morales M and Valenzuela C (2015). Carga de salmonelosis y shigelosis en cuatro departamentos de Guatemala, 2010. Revista Panamericana de Salud Pública, 38: 326332. Available https://www.scielosp.org/pdf/rpsp/2015.v38n4/326-332/es

Gil AD and Samartino L (2001). Zoonosis en los sistemas de producción animal de las áreas urbanas y periurbanas de América Latina. Food and Agriculture Organization, Roma, pp. 1 - 65. Available at: http://www.fao.org/Ag/againfo/resources/es/publications/sector_disc uss/PP_Nr2_Final.pdf

Gonzalez-Reiche AS and Perez DR (2012). Where do avian influenza viruses meet in the Americas? Avian diseases, 56(4s1): 1025-1033. DOI: https://doi.org/10.1637/10203-041412-Reg.1

Gonzalez-Reiche AS, Morales-Betoulle ME, Alvarez D, Betoulle JL, Müller ML, Sosa SM and Perez DR (2012). Influenza A viruses from wild birds in Guatemala belong to the North American lineage. PloS one, 7(3): e32873. DOI: https:// doi.org/10.1371/journal.pone.0032873

Gonzalez-Reiche AS, Nelson MI, Angel M, Müller ML, Ortiz L, Dutta J, van Bakel H, Cordon-Rosales C and Perez DR (2017). Evidence of intercontinental spread and uncommon variants of low-pathogenicity avian influenza viruses in ducks overwintering in Guatemala. Msphere, 2(2): e00362-16. DOI: https://doi.org/10.1128/mSphere.00362-16

Jarquin C, Alvarez D, Morales O, Morales AJ, López B, Donado P, Valencia MF, Arévalo A, Muñoz F, Walls I et al. (2015). Salmonella on raw poultry in retail markets in Guatemala: Levels, antibiotic susceptibility, and serovar distribution. Journal of food protection, 78(9): 1642-1650. DOI: https://doi.org/10.4315/0362028X.JFP-15-117
Kilany WH, Arafa A, Erfan AM, Ahmed MS, Nawar AA, Selim AA, Khoulosy SG, Hassan MK, Aly MM, Hafez HM et al. (2010). Isolation of highly pathogenic avian influenza $\mathrm{H} 5 \mathrm{~N} 1$ from table eggs after vaccinal break in commercial layer flock. Avian Diseases, 54(3): 1115-1119. DOI: https://doi.org/10.1637/9369041310-Case.1

Kojima A, Ishii Y, Ishihara K, Esaki H, Asai T, Oda C, Tamura Y, Takahashi $T$ and Yamaguchi $K$ (2005). Extended-spectrum- $\beta$ lactamase-producing Escherichia coli strains isolated from farm animals from 1999 to 2002: report from the Japanese Veterinary Antimicrobial Resistance Monitoring Program. Antimicrobial agents and chemotherapy, 49(8): 3533-3537. DOI: https://doi.org/10.1128/AAC.49.8.3533-3537.2005

Krumperman PH (1983). Multiple antibiotic resistance indexing of Escherichia coli to identify high-risk sources of fecal contamination of foods. Applied and Environmental Microbiology, 46(1): 165-170. Available at: https://aem.asm.org/content/46/1/165.short

Lee KM, Runyon M, Herrman TJ, Phillips R and Hsieh J (2015). Review of Salmonella detection and identification methods: aspects of rapid emergency response and food safety. Food Control Journal, 47: 264276. DOI: https://doi.org/10.1016/j.foodcont.2014.07.011

Linton AH, Howe K, Bennett PM, Richmond MH and Whiteside EJ (1977). The colonization of the human gut by antibiotic resistant Escherichia coli from chickens. Journal of Applied Bacteriology, 43(3): 465-469. DOI: https://doi.org/10.1111/j.13652672.1977.tb00773.x

Mérida-Ruíz SA, Guerra-Centeno DS, Bailey EL, Rohn K, Kösters S and Kreienbrock L (2016). Participatory epidemiology at the neotropics: study of diseases of backyard livestock and description of hunting patterns in Uaxactún, Maya Reserve Biosphere, Guatemala. BMC research notes, 9(1): 207. DOI: https://doi.org/10.1186/s13104-0162009-3

Ministry of Agriculture, Livestock and Food, Guatemala. (2019). Government Agreement 195-2019. Diario de Centro América. Avalaible https://sistemas.maga.gob.gt/normativas/Normativas?sortOrder=Res umen\&categoriaId $=4$

OIE (2018a). World Organisation For Animal Health. Manual of Diagnostic Tests and Vaccines for Terrestrial Animals (mammals, birds and bees), 8th Edition. Paris. pp 831-832.

OIE (2018b). World Organisation For Animal Health. Manual of Diagnostic Tests and Vaccines for Terrestrial Animals (mammals, birds and bees), 8th Edition. Paris. pp 1738-1740.

Russell CA, Kasson PM, Donis RO, Riley S, Dunbar J, Rambaut A, Asher J, Burke S, Davis CT, Garten RJ et al (2014). Science Forum: Improving pandemic influenza risk assessment. eLIFE, 3, e03883. DOI: https://doi.org/10.7554/eLife.03883.001

Sayah RS, Kaneene JB, Johnson Y and Miller R (2005). Patterns of antimicrobial resistance observed in Escherichia coli isolates obtained from domestic-and wild-animal fecal samples, human septage, and surface water. Applied and Environmental Microbiology, 71(3): 1394-1404. DOI: https://doi.org/10.1128/AEM.71.3.1394-1404.200

Singh S, Yadav AS, Singh SM and Bharti P (2010). Prevalence of Salmonella in chicken eggs collected from poultry farms and marketing channels and their antimicrobial resistance. Food Research International, 43(8): 2027-2030. DOI: https://doi.org/10.1016/j.foodres.2010.06.001

Sonaiya EB, Branckaert RDS and Gueye EF (1999). Research and development options for family poultry. In Food and Agriculture Organization (Editor), The scope and effect of family poultry research and development. First INFPD/FAO Electronic Conference on Family Poultry, FAO, Rome p. 3-18 (It). Available at: http://www.fao.org/3/aq635e/aq635e.pdf

Telzak EE, Budnick LD, Greenberg MS, Blum S, Shayegani M, Benson CE and Schultz S (1990). A nosocomial outbreak of Salmonella enteritidis infection due to the consumption of raw eggs. New 
England Journal of Medicine, 323(6): 394-397. DOI: https://doi.org/10.1056/NEJM199008093230607

Tian G, Zhang S, Li Y, Bu Z, Liu P, Zhou J, Li C, Shi J, Yu K and Chen $H$ (2005). Protective efficacy in chickens, geese and ducks of an H5N1-inactivated vaccine developed by reverse genetics. Virology, 341(1): 153-162. DOI: https://doi.org/10.1016/j.virol.2005.07.011

Van den Bogaard AE and Stobberingh EE (2000). Epidemiology of resistance to antibiotics: links between animals and humans. International journal of antimicrobial agents, 14(4): 327335. DOI: https://doi.org/10.1016/S0924-8579(00)00145-X
World Health Organization (WHO) (2005). Avian influenza: assessing the pandemic threat (No. WHO/CDS/2005.29). World Health Organization, Geneva. pp. 1-62. Available at: https://apps.who.int/iris/bitstream/handle/10665/68985/WHO_CDS_ 2005.29.pdf

World Health Organization (WHO) (2018). Salmonella (non typhoidal). Descriptive note. Available at: http://www.who.int/mediacentre/factsheets/fs139/es/

Wray C, Todd N, McLaren IM and Beedell YE (1991). The epidemiology of Salmonella in calves: the role of markets and vehicles. Epidemiology and Infection, 107(3): 521-525. DOI https://doi.org/10.1017/s0950268800049219 